\title{
Phytosanitary conditions of winter wheat depending on fertilization with microelements
}

\section{Stan fitosanitarny pszenicy ozimej a nawożenie mikroelementami}

\author{
Bożena Cwalina-Ambroziak ${ }^{1 *}$, Małgorzata Głosek-Sobieraj ${ }^{1}$, Arkadiusz Stępień ${ }^{2}$
}

\begin{abstract}
Summary
The Boomer variety of winter wheat was cultivated in a strict plot experiment, in a system of random blocks, and in three repetitions. Seven treatments of fertilization were included in the experiment. The objective of the research was to determine the effect of a foliar application of microelements and Nano-Gro vaccine on infection of pathogens of winter wheat leaves, ears and the stem base. In both vegetation seasons, the symptoms of Septoria tritici infection were the most frequently observed on winter wheat leaves, with dominance of $50 \%$ in 2012. In that season the significant differences in Septoria disease severity were observed within fertilized treatments. Similar phenomena was recorded for brown leaf rust (Puccinia triticina) intensity - with the highest infection level at 25\%. A minor intensity of powdery mildew (Blumeria graminis) and brown leaf rust symptoms were observed in 2013. Fusarium head blight (FHB) showing minor intensity occurred in both analysed years, with significant differences between fertilizing options. In 2013, a high intensity of symptoms of Septoria disease and Cladosporium spp. and Alternaria sp. disease was observed for ears, and the effect of applied fertilization was ambiguous. On the stem base, in both years of the study, the most frequently observed symptoms were those caused by infection of Fusarium spp. and Tapesia spp., more rarely by Rhizoctonia cerealis, and occasionally by Gaeumannomyces graminis that appeared only in 2012. The applied treatments of mineral and microelement fertilization and the vaccine did not differentiate the intensity of the diseases (exceptions: infection by G. graminis in 2012, and by Tapesia spp. in 2013).
\end{abstract}

Key words: winter wheat; fertilization NPK; foliar fertilization with microelements; diseases

\section{Streszczenie}

Pszenicę ozimą odmiany Boomer uprawiano w ścisłym doświadczeniu poletkowym, w układzie losowanych bloków, w trzech powtórzeniach. Uwzględniono siedem obiektów nawozowych. Badania przeprowadzono w celu określenia wpływu dolistnego nawożenia mikroskładnikami oraz szczepionki Nano-Gro na porażenie przez patogeny liści, kłosów i podstawy źdźbła pszenicy ozimej. Najczęściej na liściach pszenicy ozimej w obydwu sezonach wegetacyjnych obserwowano objawy porażenia przez Septoria tritici, z przewagą w 2012 r. - do 50\%. We wspomnianym sezonie zanotowano istotne różnice w nasileniu septoriozy paskowanej między obiektami nawozowymi, podobnie jak w nasileniu rdzy brunatnej - najwyższe $25 \%$ porażenie. W niewielkim nasileniu objawy mączniaka prawdziwego (Blumeria graminis) i rdzy brunatnej (Puccinia triticina) stwierdzono w 2013 r. Fuzarioza kłosów (Fusarium spp.) wystąpiła w obydwu latach badań w niewielkim nasileniu, $z$ istotną różnicą między wariantami nawozowymi. W dużym nasileniu w 2013 r. wystąpiły na kłosach objawy septoriozy i czerni zbóż, a wpływ zastosowanego nawożenia był niejednoznaczny. Na podstawie źdźbła w obydwu latach badań najczęściej obserwowano objawy porażenia przez Fusarium spp. i Tapesia spp., rzadziej przez Rhizoctonia cerealis, a tylko w 2012 r. sporadyczne porażenie przez Gaeumannomyces graminis. Zastosowane warianty nawożenia mineralnego i mikroelementami oraz szczepionka nie różnicowały nasilenia chorób (wyjątek porażenie przez G. graminis w 2012 r. i przez Tapesia spp. w 2013 r.).

Słowa kluczowe: pszenica ozima; nawożenie NPK; dolistne nawożenie mikroelementami; choroby

\footnotetext{
Uniwersytet Warmińsko-Mazurski w Olsztynie

${ }^{1}$ Katedra Entomologii, Fitopatologii i Diagnostyki Molekularnej

Prawocheńskiego 17, 10-721 Olsztyn

${ }^{2}$ Katedra Agroekosystemów

PI. Łódzki 3, 10-727 Olsztyn

*corresponding author: bambr@uwm.edu.pl
} 


\section{Wstęp / Introduction}

Choroby liści, kłosa i podstawy źdźbła zbóż stanowią duże zagrożenie dla plonu ilościowego i jakościowego ziarna (Kuś i wsp. 2007; Małecka i wsp. 2014). Wiele czynników agrotechnicznych ma wpływ na nasilenie chorób zbóż. Modyfikujący wpływ na porażenie patogenami liści i kłosa ma nawożenie mineralne (Sharma i wsp. 2005; Subedi i wsp. 2007; Thompson i Huber 2007). Małecka i wsp. (2014), objawy chorób podstawy źdźbła i korzeni obserwowali częściej w uproszczonej uprawie roli i siewie bezpośrednim w porównaniu do tradycyjnej uprawy roli, a Boligłowa i Lepiarczyk (2006) wskazują na zróżnicowanie odmian w podatności na zgorzel podstawy źdźbła. Ograniczenie występowania sprawców chorób podsuszkowych, jak twierdzą Bailey i Lazarovits (2003), powoduje również nawożenie organiczne, które sprzyja aktywności mikroorganizmów i zwiększa zawartość węgla w glebie.

Nawożenie dolistne mikroelementami warunkuje prawidłowy przebieg procesów biochemicznych w roślinie. Jest szczególnie ważne w intensywnej uprawie zbóż. W naszym kraju jego znaczenie również rośnie. Niedobór tych składników na glebach o właściwym pH i w warunkach prawidłowego nawożenia NPK może limitować wielkość plonu (Sztuder i Świerczewska 2002; Kocoń 2009). Za zasadnością stosowania dolistnego nawożenia roślin przemawia szybkie, efektywne pobieranie składników przez korzenie, z czym wiąże się małe zanieczyszczenie środowiska przyrodniczego oraz względy ekonomiczne wskutek łącznej aplikacji z nawożeniem azotowym i środkami ochrony roślin (Kuś i wsp. 2007; Szewczuk i Sugier 2009). Grzebisz i wsp. (2010) informują, że makro- i mikroelementy mają duże znaczenie w zwiększaniu odporności pszenicy na porażenie patogenami liści, kłosów, podstawy źdźbła i korzeni.

Badania podjęto w celu przeanalizowania wpływu nawożenia mineralnego NPK i dolistnego mikroelementami oraz szczepionki Nano-Gro na porażenie liści, kłosów i podstawy źdźbła pszenicy ozimej przez grzyby patogeniczne.

\section{Materiały i metody / Materials and methods}

Pszenicę ozimą (Triticum aestivum L.) odmiany Boomer uprawiano w latach 2012 i 2013 w Zakładzie Dydaktyczno-Doświadczalnym w Tomaszkowie na glebie piaszczystej klasy IVb. W doświadczeniu założonym przez Katedrę Agroekosystemów (układ losowanych bloków, w trzech powtórzeniach) uwzględniono 7 obiektów nawozowych: 1. kontrolny bez nawożenia; 2 . NPK $(90 \mathrm{~kg} / \mathrm{ha} \mathrm{N}$, $70 \mathrm{~kg} / \mathrm{ha} \mathrm{P}_{2} \mathrm{O}_{5}$ i $100 \mathrm{~kg} / \mathrm{ha} \mathrm{K}_{2} \mathrm{O} ; 3$. NPK (jak w obiekcie 2.) + nawożenie dolistne $0,2 \mathrm{~kg} / \mathrm{ha} \mathrm{Cu} ; 4$. NPK (jak w obiekcie 2.) + nawożenie dolistne $0,2 \mathrm{~kg} / \mathrm{ha} \mathrm{Zn} ; 5$. NPK (jak w obiekcie 2.) + nawożenie dolistne $0,2 \mathrm{~kg} / \mathrm{ha} \mathrm{Mn;} 6$. NPK (jak w obiekcie 2.) + nawożenie dolistne $\mathrm{Cu}, \mathrm{Zn}, \mathrm{Mn}$ (w dawce jw.); 7. NPK (jak w obiekcie 2.) + Nano-Gro. Nawożenie azotem stosowano w ilości $90 \mathrm{~kg} / \mathrm{ha}$ w dwóch terminach: w fazie krzewienia $(\mathrm{BBCH} 21) \mathrm{w}$ dawce $54 \mathrm{~kg} / \mathrm{ha} \mathrm{N}$ w postaci $34 \%$ saletry amonowej, w fazie strzelania w źdźbło (BBCH 30-31) w dawce $36 \mathrm{~kg} / \mathrm{ha} \mathrm{N}$ w postaci $46 \%$ mocznika (dolistnie $10 \%$ roztwór). Przedsiewnie zastosowano nawożenie fosforem i potasem w ilości $70 \mathrm{~kg} / \mathrm{ha} \mathrm{P}_{2} \mathrm{O}_{5} \mathrm{~W}$ formie superfosfatu potrójnego i $100 \mathrm{~kg} / \mathrm{ha} \mathrm{K}_{2} \mathrm{O}$ w formie soli potasowej. Opryskiwanie dolistne mikroelementami przeprowadzono w fazie strzelania w źdźbło (BBCH 30-31), $\mathrm{Cu}$ w dawce $0,2 \mathrm{~kg} / \mathrm{ha}$ w formie $1 \%$ roztworu $\mathrm{CuSO}_{4}, \mathrm{Zn}$ w dawce $0,2 \mathrm{~kg} / \mathrm{ha}$ w formie $1 \%$ roztworu $\mathrm{ZnSO}_{4}, \mathrm{Mn}$ w dawce $0,2 \mathrm{~kg} / \mathrm{ha}$ w formie $0,5 \%$ roztworu $\mathrm{MnSO}_{4}$. Nano-Gro o składzie chemicznym: siarczany - Fe, Co, Al, Mg, Mn, Ni i Ag w stężeniu 0,000000001 mola, cukier oczyszczony metanolem (1 $000 \mathrm{~g}$ cukru/20 ml alkoholu) zostało zarejestrowane przez Ministerstwo Rolnictwa i Rozwoju Wsi jako organiczny stymulator wzrostu roślin - decyzje S-8/09, $\mathrm{S}-8 \mathrm{a} / 10, \mathrm{~S}-8 \mathrm{~b} / 11$.

Wszystkie zabiegi uprawowe (siew, ochrona roślin, nawożenie, zbiór) prowadzono zgodnie z wymogami agrotechnicznymi odpowiednimi dla analizowanego gatunku zboża.

W okresie wegetacji na 20 losowo pobranych roślinach z poletka oceniano nasilenie występowania następujących chorób na liściu podflagowym i flagowym (w fazie pełnej dojrzałości mlecznej BBCH 75): mączniaka prawdziwego Blumeria graminis, septoriozy paskowanej Mycosphaerella graminicola st. kon. Septoria tritici i rdzy brunatnej Puccinia triticina oraz na kłosach (koniec fazy dojrzałości mlecznej BBCH 79): mączniaka prawdziwego B. graminis, septoriozy plew Phaeosphaeria nodorum st. kon. Septoria nodorum, fuzariozy kłosa Fusarium spp., czernienia zbóż (kompleks grzybów). Posłużono się następującą skalą: $0^{\circ}-$ zdrowe części nadziemne rośliny, $1^{\circ}-$ do $5 \%$ porażonej powierzchni, $2^{\circ}-6$ do $10 \%, 3^{\circ}-11$ do $30 \%, 4^{\circ}-31$ do $50 \%, 5^{\circ}>$ niż $50 \%$. Po przywiezieniu do laboratorium na podstawie źdźbła 30 losowo pobranych roślin z poletka (faza dojrzałości woskowej BBCH 85-87) szacowano nasilenie: zgorzeli Gaeumannomyces graminis, łamliwości Oculimacula spp. st. kon. Tapesia spp., fuzariozy Fusarium spp. i ostrej plamistości oczkowej Ceratobasidium cereale st. kon. Rhizoctonia cerealis według $3^{\circ}$ skali (gdzie $0^{\circ}$ - oznacza brak objawów choroby, $1^{\circ}-$ słabe objawy, $2^{\circ}$ - silne objawy). Wyniki przedstawiono w postaci indeksu porażenia, wyliczonego w procentach według wzoru Mc Kinneya (Łacicowa 1970). Otrzymane wyniki opracowano statystycznie (STATISTICA v. 10.0). W celu porównania średnich użyto testu Duncana, przyjmując poziom istotności $\alpha=0,05$.

Średnie temperatury miesięczne w analizowanych sezonach wegetacyjnych, w tym w lipcu i sierpniu, kształtowały się na poziomie średniej miesięcznej $\mathrm{z}$ wielu lat. Kwiecień i lipiec były cieplejsze w 2012 r., a maj i czerwiec w 2013 r. Sumy opadów w analizowanych miesiącach w 2012 r. były wyższe, a w 2013 r. porównywalne z sumą opadów w analogicznym okresie $\mathrm{z}$ wielu lat. Rozkład opadów w analizowanych miesiącach był podobny, z wyjątkiem kwietnia i czerwca (tab. 1).

\section{Wyniki i dyskusja / Results and discussion}

W obydwu analizowanych sezonach wegetacyjnych na liściach pszenicy ozimej stwierdzono występowanie septo- 
Tabela 1. Warunki pogodowe według Stacji Meteorologicznej w Tomaszkowie (2012-2013)

Table 1. Weather conditions according to the Meteorological Station in Tomaszkowo (2012-2013)

\begin{tabular}{l|c|c|c|c|c|c}
\hline \multirow{2}{*}{ Miesiąc - Month } & \multicolumn{2}{|c|}{2012} & \multicolumn{2}{c|}{2013} & \multicolumn{2}{c}{$1961-2000$} \\
\cline { 2 - 8 } & $\begin{array}{c}\text { temperatura } \\
\text { temperature } \\
{\left[{ }^{\circ} \mathrm{C}\right]}\end{array}$ & $\begin{array}{c}\text { opady } \\
\text { rainfall } \\
{[\mathrm{mm}]}\end{array}$ & $\begin{array}{c}\text { temperatura } \\
\text { temperature } \\
{\left[{ }^{\circ} \mathrm{C}\right]}\end{array}$ & $\begin{array}{c}\text { opady } \\
\text { rainfall } \\
{[\mathrm{mm}]}\end{array}$ & $\begin{array}{c}\text { temperatura } \\
\text { temperature } \\
{\left[{ }^{\circ} \mathrm{C}\right]}\end{array}$ & $\begin{array}{c}\text { opady } \\
\text { rainfall } \\
{[\mathrm{mm}]}\end{array}$ \\
\hline Kwiecień - April & 7,8 & 73,1 & 5,9 & 28,5 & 7,7 & 33,3 \\
\hline Maj-May & 13,4 & 51,7 & 14,8 & 54,5 & 13,5 & 58,5 \\
\hline Czerwiec - June & 15,0 & 103,2 & 17,5 & 61,2 & 16,1 & 80,4 \\
\hline Lipiec- July & 19,0 & 121,0 & 18,0 & 121,9 & 18,7 & 74,2 \\
\hline Sierpień - August & 17,7 & 45,1 & 17,4 & 37,6 & 17,9 & 59,4 \\
\hline $\begin{array}{l}\text { Średnia/Suma } \\
\text { Mean/Sum }\end{array}$ & 14,6 & 394,1 & 14,7 & 303,7 & 14,8 & 305,8 \\
\hline
\end{tabular}

riozy paskowanej i rdzy brunatnej, z istotną przewagą nasilenia objawów w 2012 r. Spośród wymienionych chorób najczęściej identyfikowano objawy septoriozy na liściach. W pierwszym spośród analizowanych sezonów wegetacyjnych zanotowano istotnie wyższe nasilenie objawów chorobowych (45-50\% porażenie) na roślinach w obiekcie kontrolnym, NPK, NPK $+\mathrm{Cu}, \mathrm{NPK}+\mathrm{Zn}$ w porównaniu do roślin w obiekcie NPK $+\mathrm{Cu}+\mathrm{Zn}+\mathrm{Mn}(28 \%)$. Niezróżnicowane istotnie wartości porażenia w kolejnym sezonie wegetacyjnym wahały się od około $29 \%$ (NPK + $\mathrm{Cu})$ do około $37 \%(\mathrm{NPK}+\mathrm{Zn})$. Zanotowano $25 \%$ porażenie roślin przez $P$. triticina $\mathrm{w}$ obiekcie kontrolnym i NPK + Zn w 2012 r., z istotną różnicą do indeksu porażenia roślin w obiekcie NPK. Warunki panujące w 2013 r. nie sprzyjały rozwojowi rdzy brunatnej, a porażenie wynosiło zaledwie $2 \%$. Objawy mączniaka prawdziwego zbóż i traw w niewielkim nasileniu, nie przekraczającym 2\% obserwowano tylko w 2013 r. (tab. 2). Zauważa się, że w obiekcie z nawożeniem NPK, również $\mathrm{w}$ niektórych obiektach $\mathrm{z}$ dolistnym nawożeniem mikroelementami, porażenie liści pszenicy ozimej przez $S$. tritici i $P$. triticina (wyjątek nasilenie $P$. triticina w obiekcie NPK w 2012 r.) było wyższe niż w obiekcie kontrolnym bez nawożenia. Jedynie w 2012 r. w obiekcie $\mathrm{NPK}+\mathrm{Cu}+\mathrm{Zn}+\mathrm{Mn}$ zanotowano istotnie niższe porażenie przez sprawcę septoriozy paskowanej w stosunku do obiektu kontrolnego, NPK, NPK $+\mathrm{Cu}$ i NPK $+\mathrm{Zn}$. Analizując średnie za dwa lata badań stwierdza się, że powyższy patogen istotnie częściej porażał liście pszenicy w obiekcie NPK i NPK + Zn. Wzrost nawożenia N może powodować nasilanie się objawów takich chorób, jak: mączniaka prawdziwego, rdzy brunatnej czy rdzy żółtej (Thompson i Huber 2007). Simoglou i Dordas (2006) wykazali, że zastosowanie manganu w formie nawożenia dolistnego istotnie obniżyło porażenie liści pszenicy w stosunku do kontroli i pozostałych obiektów nawozowych. Zastosowanie mieszaniny fungicydu Topsin M 500 SC z nawozem dolistnym Mantrac (Mn) 500 przyczyniło się do zwiększenia zdrowotności roślin pszenicy ozimej oraz poprawiło skuteczność grzybobójczą zabiegu, w odniesieniu do liści i podstawy źdźbła pszenicy ozimej (Sawinska i Banach 2007). Grzebisz i wsp. (2010) informują o mniejszym nasileniu na liściach objawów mączniaka prawdziwego zbóż i traw pod wpływem nawożenia K, S i Mn, rdzy brunatnej pod wpływem nawożenia $\mathrm{K}$, $\mathrm{Mn}$ i $\mathrm{Cl}$ oraz septoriozy paskowanej na roślinach nawożonych $\mathrm{K} \mathrm{i} \mathrm{Cl}$.

W pierwszym sezonie wegetacyjnym niniejszych badań kłosy pszenicy ozimej były porażone jedynie przez grzyby rodzaju Fusarium, a zaledwie 4,5\% porażenie zanotowano na roślinach $\mathrm{w}$ obiekcie ze stosowanym nawożeniem mineralnym i trzema mikroelementami łącznie, $\mathrm{z}$ istotną różnicą do obiektu kontrolnego, NPK, NPK + Cu, NPK + Mn. Częściej w porównaniu do 2012 r. objawy fuzariozy kłosów wystąpiły w sezonie wegetacyjnym 2013 r., w którym czerwiec i lipiec były ciepłe, z opadami jedynie w lipcu wyższymi niż średnie $\mathrm{z}$ wielolecia. Nasilenie objawów omawianej choroby wahało się od 4,6\% w obiekcie NPK + Zn do około $12 \%$ w obiekcie NPK + Nano-Gro; różnice $\mathrm{w}$ wartościach indeksów między obiektami były istotne. Średnie z dwóch lat badań wskazują na istotnie większe porażenie kłosów w obiekcie ze szczepionką Nano-Gro w stosunku do pozostałych obiektów (wyjątek $\mathrm{NPK}+\mathrm{Cu}$ ). Czynnikami sprzyjającymi rozwojowi fuzariozy kłosów, o czym informują Champeil i wsp. (2004), jest wysoka wilgotność powietrza, wiatr i opady deszczu. Lemmens i wsp. (2004) oraz Heier i wsp. (2005) wskazują natomiast na istotny wzrost nasilenia fuzariozy kłosów pod wpływem nawożenia N stosowanego przed wykłoszeniem, co thumaczą zmianą charakterystyki uprawy i specyficznego mikroklimatu. Aplikacja $\mathrm{N}$ po wykłoszeniu, jak twierdzą Kimura i wsp. (2001), nie zmienia gęstości uprawy. Subedi i wsp. (2007) przeciwnie, dowodzą, że zastosowane w czasie kwitnienia nawożenie $\mathrm{N}$ w dawce $60 \mathrm{i} 100 \mathrm{~kg} /$ ha ograniczało infekcje grzybami.

Zróżnicowanie w porażeniu przez pozostałe patogeny: S. nodorum, B. graminis i sprawców czernienia zbóż między analizowanymi obiektami nawozowymi było nieistotne. Stwierdzono najsilniejsze objawy infekcji przez kompleks grzybów - indeksy porażenia od około 30\% $(\mathrm{NPK}+\mathrm{Zn})$ do około 40\% (NPK + Mn). Septorioza kłosów wystąpiła $\mathrm{w}$ słabszym nasileniu na poziomie $16 \%$ (obiekt kontrolny, NPK $+\mathrm{Cu}+\mathrm{Zn}+\mathrm{Mn}$ ) do $23 \%(\mathrm{NPK}+$ $\mathrm{Mn})$. Groźny patogen zbóż $B$. graminis dawał sporadyczne objawy porażenia kłosów, tylko w niektórych obiektach (tab. 3). Grzebisz i wsp. (2010) w swoich badaniach wskazują na ograniczający wpływ $\mathrm{K}, \mathrm{Mn}, \mathrm{Cl}$ i B na rozwój sprawców rdzy żółtej na kłosach pszenicy, a $\mathrm{Cu}$ - sprawców sporyszu. Ponadto autorzy dowodzą słabszej infekcji 
Tabela 2. Porażenie liści pszenicy ozimej przez patogeny - indeks porażenia [Ip \%]

Table 2. Infection of leaves of winter wheat by pathogens - index of infection [Ii \%]

\begin{tabular}{|c|c|c|c|c|c|c|c|c|c|}
\hline \multirow[b]{2}{*}{ Obiekt - Treatments } & \multicolumn{3}{|c|}{ Blumeria graminis } & \multicolumn{3}{|c|}{ Septoria tritici } & \multicolumn{3}{|c|}{ Puccinia triticina } \\
\hline & 2012 & 2013 & $\begin{array}{c}\text { średnia } \\
\text { mean }\end{array}$ & 2012 & 2013 & $\begin{array}{c}\text { średnia } \\
\text { mean }\end{array}$ & 2012 & 2013 & $\begin{array}{c}\text { średnia } \\
\text { mean }\end{array}$ \\
\hline Kontrola - Control & $0 \mathrm{~b}$ & $0,2 \mathrm{~b}$ & $0,1 \mathrm{~K}$ & $43,5 \mathrm{abc}$ & $34,9 \mathrm{~cd}$ & $39,2 \mathrm{KL}$ & $24,7 \mathrm{a}$ & $0,5 \mathrm{c}$ & $12,6 \mathrm{~K}$ \\
\hline NPK 90 & $0 \mathrm{~b}$ & $0,1 \mathrm{~b}$ & $0,1 \mathrm{~K}$ & $51,7 \mathrm{a}$ & $35,3 \mathrm{~cd}$ & $43,5 \mathrm{~K}$ & $19,3 \mathrm{~b}$ & $1,7 \mathrm{c}$ & $10,5 \mathrm{~K}$ \\
\hline $\mathrm{NPK}+\mathrm{Cu}$ & $0 \mathrm{~b}$ & $0,7 \mathrm{ab}$ & $0,4 \mathrm{~K}$ & $51,0 \mathrm{ab}$ & $28,7 \mathrm{~d}$ & $38,9 \mathrm{KL}$ & $22,3 \mathrm{ab}$ & $1,5 \mathrm{c}$ & $11,9 \mathrm{~K}$ \\
\hline $\mathrm{NPK}+\mathrm{Zn}$ & $0 \mathrm{~b}$ & $0,3 \mathrm{~b}$ & $0,1 \mathrm{~K}$ & $44,7 \mathrm{abc}$ & $36,7 \mathrm{~cd}$ & $40,7 \mathrm{~K}$ & $25,0 \mathrm{a}$ & $1,4 \mathrm{c}$ & $13,3 \mathrm{~K}$ \\
\hline $\mathrm{NPK}+\mathrm{Mn}$ & $0 \mathrm{~b}$ & $1,6 \mathrm{a}$ & $0,8 \mathrm{~K}$ & $37,5 \mathrm{bcd}$ & $33,4 \mathrm{~cd}$ & $35,5 \mathrm{KL}$ & $21,0 \mathrm{ab}$ & $1,8 \mathrm{c}$ & $11,4 \mathrm{~K}$ \\
\hline $\mathrm{NPK}+\mathrm{Zn}+\mathrm{Cu}+\mathrm{Mn}$ & $0 \mathrm{~b}$ & $1,7 \mathrm{a}$ & $0,9 \mathrm{~K}$ & $28,3 \mathrm{~d}$ & $32,1 \mathrm{~cd}$ & $30,2 \mathrm{~L}$ & $23,2 \mathrm{ab}$ & $1,3 \mathrm{c}$ & $12,2 \mathrm{~K}$ \\
\hline NPK + Nano-Gro & $0 \mathrm{~b}$ & $1,0 \mathrm{ab}$ & $0,5 \mathrm{~K}$ & 38,4 a-d & $33,8 \mathrm{~cd}$ & $36,1 \mathrm{KL}$ & $21,7 \mathrm{ab}$ & $1,9 \mathrm{c}$ & $11,8 \mathrm{~K}$ \\
\hline Średnia - Mean & $0 \mathrm{~B}$ & $0,8 \mathrm{~A}$ & - & $42,2 \mathrm{~A}$ & $33,5 \mathrm{~B}$ & - & $22,4 \mathrm{~A}$ & $1,5 \mathrm{~B}$ & - \\
\hline
\end{tabular}

Statystyka w obrębie choroby - Statistics for diseases

Średnie oznaczone tą samą literą nie różnią się między sobą na poziomie istotności $\alpha=0,05$

Means followed by the same letter do not differ significantly at $\alpha=0.05$

Tabela 3. Porażenie kłosów pszenicy ozimej przez patogeny - indeks porażenia [Ip \%]

Table 3. Infection of ears of winter wheat by pathogens - index of infection [Ii \%]

\begin{tabular}{l|c|c|c|c|c|c}
\hline \multirow{2}{*}{ Obiekt - Treatments } & \multicolumn{3}{|c|}{ Fusarium spp. } & $\begin{array}{c}\text { Septoria } \\
\text { nodorum }\end{array}$ & $\begin{array}{c}\text { Kompleks grzybów } \\
\text { Complex of fungi }\end{array}$ & $\begin{array}{c}\text { Blumeria } \\
\text { graminis }\end{array}$ \\
\cline { 2 - 7 } & 2012 & 2013 & $\begin{array}{c}\text { średnia } \\
\text { mean }\end{array}$ & 2013 & 2013 & 2013 \\
\hline Kontrola - Control & $1,0 \mathrm{f}$ & $6,1 \mathrm{~cd}$ & $3,5 \mathrm{M}$ & $16,2 \mathrm{a}$ & $32,5 \mathrm{a}$ & $0 \mathrm{a}$ \\
\hline $\mathrm{NPK} 90$ & $1,5 \mathrm{f}$ & $8,5 \mathrm{bc}$ & $5,0 \mathrm{LM}$ & $22,2 \mathrm{a}$ & $31,5 \mathrm{a}$ & $0,2 \mathrm{a}$ \\
\hline $\mathrm{NPK}+\mathrm{Cu}$ & $1,5 \mathrm{f}$ & $9,7 \mathrm{ab}$ & $5,6 \mathrm{KL}$ & $20,8 \mathrm{a}$ & $36,4 \mathrm{a}$ & $0 \mathrm{a}$ \\
\hline $\mathrm{NPK}+\mathrm{Zn}$ & $2,5 \mathrm{ef}$ & $4,6 \mathrm{de}$ & $3,6 \mathrm{M}$ & $19,0 \mathrm{a}$ & $29,5 \mathrm{a}$ & $0 \mathrm{a}$ \\
\hline $\mathrm{NPK}+\mathrm{Mn}$ & $0 \mathrm{f}$ & $8,5 \mathrm{bc}$ & $4,3 \mathrm{LM}$ & $23,2 \mathrm{a}$ & $38,8 \mathrm{a}$ & $0 \mathrm{a}$ \\
\hline NPK $+\mathrm{Zn}+\mathrm{Cu}+\mathrm{Mn}$ & $4,5 \mathrm{de}$ & $5,9 \mathrm{~d}$ & $5,2 \mathrm{LM}$ & $16,6 \mathrm{a}$ & $37,2 \mathrm{a}$ & $0,6 \mathrm{a}$ \\
\hline NPK $+\mathrm{Nano}-\mathrm{Gro}$ & $2,5 \mathrm{ef}$ & $11,9 \mathrm{a}$ & $7,2 \mathrm{~K}$ & $18,0 \mathrm{a}$ & $37,6 \mathrm{a}$ & $0,6 \mathrm{a}$ \\
\hline Średnia - Mean & $1,9 \mathrm{~B}$ & $7,9 \mathrm{~A}$ & - & - & - & - \\
\hline
\end{tabular}

Statystyka w obrębie choroby - Statistics for diseases

Średnie oznaczone tą samą literą nie różnią się między sobą na poziomie istotności $\alpha=0,05$

Means followed by the same letter do not differ significantly at $\alpha=0.05$

Tabela 4. Porażenie podstawy źdźbła pszenicy ozimej przez patogeny - indeks porażenia [Ip \%]

Table 4. Infection of stem base of winter wheat by pathogens - index of infection [Ii \%]

\begin{tabular}{|c|c|c|c|c|c|c|c|c|c|c|c|c|}
\hline \multirow{2}{*}{$\begin{array}{c}\text { Obiekt } \\
\text { Treatments }\end{array}$} & \multicolumn{3}{|c|}{ Gaeumannomyces graminis } & \multicolumn{3}{|c|}{ Tapesia spp. } & \multicolumn{3}{|c|}{ Fusarium spp. } & \multicolumn{3}{|c|}{ Rhizoctonia cerealis } \\
\hline & 2012 & 2013 & $\begin{array}{c}\text { średnia } \\
\text { mean }\end{array}$ & 2012 & 2013 & $\begin{array}{c}\text { średnia } \\
\text { mean }\end{array}$ & 2012 & 2013 & $\begin{array}{c}\text { średnia } \\
\text { mean }\end{array}$ & 2012 & 2013 & $\begin{array}{c}\text { średnia } \\
\text { mean }\end{array}$ \\
\hline $\begin{array}{l}\text { Kontrola } \\
\text { Control }\end{array}$ & $0 \mathrm{c}$ & $0 \mathrm{c}$ & $0 \mathrm{~L}$ & $19,2 \mathrm{de}$ & $35,5 \mathrm{abc}$ & $27,4 \mathrm{KL}$ & $38,5 \mathrm{ab}$ & $52,5 \mathrm{a}$ & $45,5 \mathrm{~K}$ & $0,3 \mathrm{c}$ & $9,0 \mathrm{a}$ & $4,6 \mathrm{~K}$ \\
\hline NPK 90 & $3,6 \mathrm{~b}$ & $0 \mathrm{c}$ & $1,8 \mathrm{KL}$ & $20,8 \mathrm{de}$ & $35,4 \mathrm{abc}$ & $28,1 \mathrm{KL}$ & $28,6 \mathrm{~b}$ & $37,6 \mathrm{ab}$ & $33,1 \mathrm{~L}$ & $1,4 \mathrm{bc}$ & $6,0 \mathrm{abc}$ & $3,7 \mathrm{~K}$ \\
\hline $\mathrm{NPK}+\mathrm{Cu}$ & $1,4 \mathrm{bc}$ & $0 \mathrm{c}$ & $0,7 \mathrm{~L}$ & $12,9 \mathrm{e}$ & $38,5 \mathrm{ab}$ & $25,7 \mathrm{KL}$ & $34,2 \mathrm{~b}$ & $42,5 \mathrm{ab}$ & $38,4 \mathrm{KL}$ & $2,1 \mathrm{abc}$ & $9,4 \mathrm{a}$ & $5,8 \mathrm{~K}$ \\
\hline $\mathrm{NPK}+\mathrm{Zn}$ & $6,5 \mathrm{a}$ & $0 \mathrm{c}$ & $3,2 \mathrm{~K}$ & 22,7 cde & $36,5 \mathrm{ab}$ & $29,6 \mathrm{KL}$ & $39,4 \mathrm{ab}$ & $39,5 \mathrm{ab}$ & $39,5 \mathrm{KL}$ & $2,9 \mathrm{abc}$ & $4,5 \mathrm{abc}$ & $3,7 \mathrm{~K}$ \\
\hline $\mathrm{NPK}+\mathrm{Mn}$ & $0 \mathrm{c}$ & $0 \mathrm{c}$ & $0 \mathrm{~L}$ & $19,3 \mathrm{de}$ & $40,5 \mathrm{ab}$ & $29,9 \mathrm{KL}$ & $32,9 \mathrm{~b}$ & $43,1 \mathrm{ab}$ & $38,0 \mathrm{KL}$ & $0,7 \mathrm{c}$ & $7,0 \mathrm{abc}$ & $3,9 \mathrm{~K}$ \\
\hline $\begin{array}{l}\mathrm{NPK}+\mathrm{Zn} \\
+\mathrm{Cu}+\mathrm{Mn}\end{array}$ & $1,4 \mathrm{bc}$ & $0 \mathrm{c}$ & $0,7 \mathrm{~L}$ & 22,3 cde & $43,0 \mathrm{a}$ & $32,7 \mathrm{~K}$ & $42,8 \mathrm{ab}$ & $38,9 \mathrm{ab}$ & $48,9 \mathrm{KL}$ & $2,2 \mathrm{abc}$ & $6,5 \mathrm{abc}$ & $4,3 \mathrm{~K}$ \\
\hline $\begin{array}{l}\text { NPK } \\
+ \text { Nano Gro }\end{array}$ & $0 \mathrm{c}$ & $0 \mathrm{c}$ & $0 \mathrm{~L}$ & $18,0 \mathrm{de}$ & $27,5 \mathrm{bcd}$ & $22,7 \mathrm{~L}$ & $30,0 \mathrm{~b}$ & $43,5 \mathrm{ab}$ & $36,8 \mathrm{KL}$ & $0 \mathrm{c}$ & $8,5 \mathrm{ab}$ & $4,2 \mathrm{~K}$ \\
\hline $\begin{array}{l}\text { Średnia } \\
\text { Mean }\end{array}$ & $1,8 \mathrm{~A}$ & $0,0 \mathrm{~B}$ & & $19,3 \mathrm{~B}$ & $36,7 \mathrm{~A}$ & - & $35,2 \mathrm{~B}$ & $42,5 \mathrm{~A}$ & - & 1,3 B & $7,3 \mathrm{~A}$ & - \\
\hline
\end{tabular}

Statystyka w obrębie choroby - Statistics for diseases

Średnie oznaczone tą samą literą nie różnią się między sobą na poziomie istotności $\alpha=0,05$

Means followed by the same letter do not differ significantly at $\alpha=0.05$ 
podstawy źdźbła przez G. graminis w warunkach nawożenia N w formie amonowej (również przez Tapesia spp.) i Mn, $\mathrm{Cu}$ i Cl oraz słabszej infekcji korzeni przez Fusarium spp. podczas dolistnej aplikacji Zn. Podobnie Thompson i Huber (2007) we wcześniejszych badaniach stwierdzili, że forma amonowa w większym stopniu determinuje wzrost odporności roślin na patogeny, co wynika m.in. ze zwiększonej aktywności mikroelementów, np. manganu. Wojtala i Parylak (2009) informują o ograniczeniu nasilenia objawów chorób podstawy źdźbła w warunkach obniżonej o połowę w stosunku do optymalnej dawki nawożenia N. W przeprowadzonym doświadczeniu spośród chorób podstawy źdźbła pszenicy ozimej duże zagrożenie podczas całego okresu badawczego stanowiła fuzaryjna zgorzel podstawy źdźbła i łamliwość źdźbła zbóż i traw. Nasilenie fuzariozy wahało się od $29 \%$ na roślinach $\mathrm{w}$ obiekcie $\mathrm{z}$ nawożeniem mineralnym do $43 \% \mathrm{z}$ nawożeniem mineralnym i trzema mikroelementami łącznie w 2012 r. i od $38 \%$ w obiekcie $\mathrm{z}$ nawożeniem NPK do 52,5\% w obiekcie kontrolnym w 2013 r. Różnice w nasileniu choroby między poszczególnymi obiektami doświadczenia w obydwu analizowanych terminach były nieistotne, dopiero średnie $\mathrm{z}$ dwóch lat wskazują na istotne różnice pomiędzy obiektem kontrolnym i NPK. Objawy łamliwości podstawy źdźbła, podobnie jak fuzariozy, w mniejszym stopniu zaobserwowano na roślinach w $2012 \mathrm{r}$. - od $13 \%(\mathrm{NPK}+\mathrm{Cu})$ do około $23 \%(\mathrm{NPK}+\mathrm{Zn}, \mathrm{NPK}+$ $\mathrm{Cu}+\mathrm{Zn}+\mathrm{Mn})$ niż w 2013 r. - od 27,5\% (NPK + NanoGro) do 43,5\% (NPK $+\mathrm{Zn}+\mathrm{Cu}+\mathrm{Mn})$. W ostatnim roku badań różnice zanotowane między powyższymi obiektami były istotne, co potwierdzają średnie $\mathrm{z}$ całego okresu badawczego. Stwierdzić zatem można, że nawożenie mineralne $\mathrm{z}$ trzema mikroelementami łącznie sprzyjało rozwojowi łamliwości źdźbła zbóż. Pozostałe choroby zgorzel podstawy źdźbła i ostra plamistość oczkowa wystąpiły w małym nasileniu. Porażenie przez sprawcę zgorzeli podstawy źdźbła zanotowano jedynie na pszenicy uprawianej w 2012 r., z istotnie wyższym indeksem porażenia $6,5 \% \mathrm{w}$ obiekcie NPK $+\mathrm{Zn}$ w porównaniu do pozostałych obiektów doświadczenia. W niektórych obiek- tach nie stwierdzono objawów tej choroby, podobnie jak we wszystkich obiektach w 2013 r. Analiza średnich z okresu badań wskazuje na istotne zróżnicowanie nasilenia choroby między obiektem NPK + Zn a pozostałymi (wyjątek NPK). Nasilenie objawów ostrej plamistości oczkowej w pierwszym sezonie wegetacyjnym w analizowanym doświadczeniu nie przekraczało $3 \%(\mathrm{NPK}+\mathrm{Zn})$, a w kolejnym sezonie 10\% (obiekt kontrolny) (tab. 4).

\section{Wnioski / Conclusions}

1. W obydwu analizowanych sezonach wegetacyjnych na liściach pszenicy ozimej najczęściej występowały objawy septoriozy i rdzy brunatnej, z większą częstotliwością w 2012 r. We wspomnianym sezonie zanotowano istotne różnice w porażeniu przez $S$. tritici między obiektami doświadczenia $\mathrm{NPK}+\mathrm{Cu}+\mathrm{Zn}+\mathrm{Mn}$ i NPK, przez P. triticina - między obiektami NPK i NPK + Zn

2. Na kłosach najczęściej obserwowano objawy czernienia zbóż i septoriozy plew w 2013 r. W mniejszym nasileniu wystąpiła fuzarioza, a sporadycznie mączniak prawdziwy. Zastosowane nawożenie mikroelementami nie różnicowało nasilenia wspomnianych chorób, $\mathrm{z}$ wyjątkiem fuzariozy $\mathrm{w}$ obydwu latach, co potwierdzają średnie za okres badań.

3. Podstawa źdźbła była najbardziej porażona przez sprawców łamliwości podstawy źdźbła i fuzariozy, z istotnie przeważającym nasileniem chorób w 2013 r. W omawianym sezonie stwierdzono istotne ograniczenie porażenia przez Tapesia spp. roślin w obiekcie z zastosowana szczepionką Nano-Gro w stosunku do obiektu $\mathrm{NPK}+\mathrm{Cu}+\mathrm{Zn}+\mathrm{Mn}$, co potwierdzają średnie z lat. Rzadziej obserwowano objawy porażenia przez $R$. cerealis, a sporadycznie przez $G$. graminis $\mathrm{Z}$ istotnym zróżnicowaniem pomiędzy obiektami w pierwszym sezonie, na co również wskazują średnie za okres badań.

\section{Literatura / References}

Bailey K.L., Lazarovits G. 2003. Suppressing soil-borne diseases with residue management and organic amendments. Soil \& Tillage Research 72: 169-180.

Boligłowa E., Lepiarczyk A. 2006. Wpływ sposobu uprawy roli na zdrowotność podstawy źdźbła pszenicy ozimej. [The influence of tillage system on winter wheat stem base healthiness]. Progress in Plant Protection/Postępy w Ochronie Roślin 46 (2): $530-532$.

Champeil A., Dore T., Fourbet J.F. 2004. Fusarium head blight: epidemiological origin of the effects of cultural practices on head blight attacks and the production of mycotoxins by Fusarium in wheat grains. Plant Science 166: 1389-1415.

Grzebisz W., Gaj R., Przygocka-Cyna K. 2010. Rola składników pokarmowych w budowaniu mechanizmów odporności roślin uprawnych na presje patogenów. [Role of nutrients in build-up of plant resistance mechanisms to pathogens pressure]. Progress in Plant Protection/Postępy w Ochronie Roślin 50 (2): 517-532.

Heier T., Jain S.K., Kogel K.H., Pons-Kühnemann J. 2005. Influence of N-fertilization and fungicide strategies on Fusarium head blight severity and mycotoxin content in winter wheat. Journal of Phytopathology 153 (9): 551-557.

Kimura M., Anzai H., Yamaguchi I. 2001. Microbial toxins in plant-pathogen interactions: Biosynthesis, resistance mechanisms, and significance. The Journal of General and Applied Microbiology 47 (4): 149-160.

Kocoń A. 2009. Efektywność dolistnego dokarmiania pszenicy i rzepaku ozimego wybranymi nawozami w warunkach optymalnego nawożenia $i$ wilgotności gleby. [Foliar top dressing efficiency of winter wheat and rape of chosen fertilizers in optimal fertilization and soil moisture conditions]. Annales Universitatis Mariae Curie-Skłodowska, Lublin - Polonia, Sectio E, LXIV (2): 23-28.

Kuś J., Jończyk K., Kawalec A. 2007. Czynniki ograniczające plonowanie pszenicy ozimej w różnych systemach gospodarowania. Acta Agrophysica 10 (2): 407-417.

Lemmens M., Haim K., Lew H., Ruckenbauer P. 2004. The effect of nitrogen fertilization on Fusarium head blight development and deoxynivalenol contamination in wheat. Journal of Phytopathology 152 (1): 1-8. 
Łacicowa B. 1970. Badanie szczepów Helminthosporium sorokinianum (H. sativum) oraz odporność odmian jęczmienia jarego na ten czynnik chorobotwórczy. Acta Mycologica 6 (2): 184-248.

Małecka I., Sawińska Z., Blecharczyk A., Dytman-Hagedorn M. 2014. Zdrowotność pszenicy ozimej w różnych wariantach uprawy roli. [Winter wheat health in different tillage methods]. Progress in Plant Protection 54 (2): 246-250.

Sawinska Z., Banach P. 2007. Wpływ łącznego stosowania fungicydu Topsin M 500 SC z nawozem dolistnym Mantrac 500 na zdrowotność pszenicy ozimej. [Influence of foliar application of fungicide Topsin SC applied with fertilizer Mantrac 500 on healt of winter wheat]. Progress in Plant Protection/Postępy w Ochronie Roślin 47 (2): 310-313.

Sharma S., Duveiller E., Basnet R., Karki C.B., Sharma R.C. 2005. Effect of potash fertilization on Helminthosporium leaf blight severity in wheat, and associated increases in grain yield and kernel weight. Field Crops Research 93 (2-3): 142-150.

Simoglou K.B., Dordas C. 2006. Effect of foliar applied boron, manganese and zinc on tan spot in winter durum wheat. Crop Protection 25 (7): 657-663.

Subedi K.D., Ma B.L., Xue A.G. 2007. Planting date and nitrogen effects on Fusarium head blight and leaf spotting diseases in spring wheat. Agronomy Journal 99 (1): 113-121.

Szewczuk C., Sugier D. 2010. Ogólna charakterystyka i podział nawozów dolistnych oferowanych na polskim rynku. Annales Universitatis Mariae Curie-Skłodowska, Lublin - Polonia, Sectio E, LXIV (1): 29-36.

Sztuder H., Świerczewska M. 2002. Wpływ nawozów dolistnych na cechy jakościowe ziarna niektórych odmian pszenicy ozimej i jarej. Zeszyty Problemowe Postępów Nauk Rolniczych 484: 669-674.

Thompson I.A., Huber D.M. 2007. Manganese and plant disease. p. 139-153. (Chapter 10). In: "Mineral Nutrition and Plant Disease" (L.E. Datnoff, W.H. Elmer, D.M. Huber, eds.). The APS, St. Paul, MN, 278 pp.

Wojtala L., Parylak D. 2009. Skuteczność zapraw nasiennych, międzyplonu i poziomu nawożenia azotowego w ograniczaniu porażenia pszenicy ozimej przez patogeny podstawy źdźbła. [Effectiveness of seed treatment, stubble crop and level of nitrogen fertilization fertilization in reducing winter wheat infection with root and stem base pathogens]. Progress in Plant Protection/Postępy w Ochronie Roślin 49 (2): 769-772. 